Dialectologia 17 (2016), 91-109.

ISSN: 2013-2247

Received 17 September 2014.

Accepted 11 January 2015.

\title{
LANGUAGE PERSONALITY AS A NEW OBJECT FOR DIALECTOLOGICAL RESEARCH ${ }^{1}$
}

\author{
Ekaterina IVANTSOVA \\ National Research Tomsk State University* \\ ekivancova@yandex.ru
}

\begin{abstract}
The article is devoted to a new object of dialectology - a language personality. This is the phenomenon of specific social and personal traits of an individual native speaker being reflected in the text the speaker creates. It analyzes the research that arose at the junction of traditional dialectology and the theory of lingvopersonology that is being performed today by Russian dialectologists. The author examines the main projects that study the speech of an individual dialect speaker, typical features of the individuals under research, types of sources used by scientists, classical and new methods of collecting and analyzing speech material, and aspects of research of individual speech of representatives of national dialects. Prospects of this research for dialectology and other fields of the science of language are identified.
\end{abstract}

\section{Keywords}

local dialects, language personality, individual speech, Russian dialectology, lingvopersonology

\footnotetext{
${ }^{1}$ The study was performed by a grant of Russian Science Foundation (project № 16-18-02043).

* Томск, 634050, пр. Ленина, 36. Department of Russian Language, National Research Tomsk State University, Lenin Avenue 36, Tomsk, Russia; postcode 634050
} 


\section{LA PERSONALIDAD LINGÜÍSTICA COM NUEVO OBJETO DE INVESTIGACIÓN DIALECTAL}

\section{Resumen}

Este artículo está dedicado a un nuevo objeto de la dialectología: la personalidad lingüística. Este es el fenómeno de rasgos sociales y personales específicos de un hablante nativo individual que se refleja en el texto que el hablante crea. Se analiza la investigación que surgió en el cruce entre la dialectología tradicional y la teoría de la linguopersonalidad que realizan actualmente los dialectólogos rusos. La autora examina los principales proyectos que estudian el habla de un hablante individual de un dialecto, las características típicas de los individuos bajo investigación, los tipos de fuentes utilizadas por los científicos, los métodos clásicos y nuevos de recolección y análisis de material hablado, y aspectos de la investigación de rasgos representativos de habla individual de dialectos nacionales. Se identifican las perspectivas de esta investigación para la dialectología y otros campos de la ciencia del lenguaje.

Palabras clave

dialectos locales, personalidad lingüística, habla individual, dialectología rusa, linguopersonalidad

\section{Introduction}

Linguistics has come a long way in the past two centuries, each step bringing it closer to understanding that a person is the main object of scientific knowledge. It was in the nineteenth century that Buschmann \& Humboldt (2000), Osthoff \& Brugmann (1881), Paul (2002), Baudouin de Courtenay (1963) and others raised the question of a ratio of the general and the individual in a language. At the beginning of the twentieth century special attention was paid to theoretical problems of studying individual speech in works of Sapir (1949), Bakhtin (1996) and Vinogradov (1980). Weisgerber (1929) defined the individual usage of a language system as one of the forms of existence of a language. In the middle of the century foundations of a communicative, functional approach, and a little later of a cognitive and linguo-culturological one, were laid in linguistics, and supplemented the traditional historical and the system-structural analyses. The central paradigm of scientific knowledge came to be anthropocentric in many sciences, including linguistics. More and more often properties of a language were analyzed for the purpose of revealing intrinsic characteristics of a person as its bearer, and vice versa: the speech of certain members of a linguistic community is a source that helps to understand properties of the language system. At last, at the beginning of the 
twenty-first century, lingvopersonology became an independent discipline with its object, methods, terminology, and a base of sources (see more: Ivantsova 2010). The task of the new area of linguistic science is to study the phenomenon of the language personality. The language personality denotes a concrete, real-life native speaker whose personal characteristics synthesizing his or her social and individual traits are reflected in the texts the speaker creates.

"Identity linguistics" made headway in the work of scientists from different countries (Pound 1947; Petkov 1983; Fillmore, Kempler \& Wang 1979; Johnstone 1996; Asahi 2009, and others), especially in the sphere of the so-called author's lexicography (dictionaries of those who founded national languages - Shakespeare, Milton, Pushkin, Goethe, Schiller and many others are widely known). At the same time, the theory and practice of linguistic personological research is developing more actively in Russian linguistics (Bogin 1984; Karaulov 1987; Neroznak 2003; Golev 2004, and others), where a number of centers for studying language personality are being established, in Moscow, Perm, Tomsk, Saratov, Krasnoyarsk, Blagoveshchensk, and elsewhere.

Dialectology plays an important role in the formation of lingvopersonology. The traditional object of this sphere is the speech of a community that speaks this or that locally limited subsystem of a nationwide language. However, due to the fact that dialects lack a written form, dialectologists had always focused on collecting language material in direct contact with dialects' speakers, taking into account some specific features of informants. Problems of dialectological research also facilitated raising and solving questions about a ratio of speech manifestations of an individual dialect speaker and the speaker's native dialect as a usual system, and about mental features and social and cultural particularities of a dialect community and individuals who belong to it. Now a dialect language personality has emerged as one of the central objects of linguistic research.

The purpose of this article is to analyze articulation of the linguistic personological direction in dialectological research and to characterize achievements of Russian linguistics in this area. 


\section{Attention to the speech of individual dialect speakers}

Analysis of dialectological research of the last century shows that interest in the personality of an individual dialect speaker has constantly increased. The main projects in this area are listed below:

-1914. An outstanding Russian philologist and historian A. Shakhmatov described one of the dialects of Ryazan Province, relying on data of a single speaker of this dialect, I.S. Grishkin (Shakhmatov 1914).

-1949-2003. V. Timofeyev systematically studied the speech of E. M. Timofeyeva, a native of the Kurgan Region born in 1897 (Timofeyev 1971, 2003). ${ }^{2}$

- From 1963 to the present. A group of scientists of Perm University has been investigating the speech of A. G. Gorshkova, an inhabitant of the Perm region, born in 1891 (Gruzberg \& Egoryeva 1969; Skitova \& Ogiyenko 1971; Malysheva 2007).

-1971-2005. V. Lyutikova analyzed the speech of a dialect speaker V. M. Petukhova, born in 1920, from the Kurgan region (Lyutikova 1999, 2000).

- From 1981 to the present. Linguists of Tomsk dialectological school have been carrying out research of the personality of an elderly resident of Siberia V. P. Vershinina, born in 1909 (Gyngazova 2001, 2008, 2009, 2010; Ivantsova 2002, 2005, 2009, 20062012, 2014; Volkova 2004; Kazakova 2007; Kuznetsova 2015, etc.).

- From 1984 to the present. The speech of members of the Lykov family, Old Believers living in the wild Sayan taiga for several decades in isolation from the outside world because of their religious beliefs, has become an object of linguistic analysis (Almukhamedova et al. 1986; Slesareva 1997; Markelov 2000; Tolstova 2004, 2007).

- From 1987 to the present time. Perm linguists headed by I. Russinova have been studying the personality of M. P. Suslova, born in 1926, an inhabitant of the Perm Region (Russinova 2007).

-1990-2008. E. Nefyodova undertook research of the speech of A. I. Ponomareva, born in 1928 in the Arkhangelsk Region (Nefyodova 1997, 2000, 2001).

\footnotetext{
${ }^{2}$ Because the volume of magazine publications is limited, hereinafter I refer only to the most significant works of the authors or to monographic studies, which summarize the results of the preceding articles.
} 
-2002-2012. E. Prokofieva studied the speech of A. V. Medvedeva, a dialect language personality from the Altai Krai, born in 1913 (Prokofieva 2012).

- At the turn of the twenty-first century, a series of speech portraits of dialect speakers was created in different dialectological centers (Oglezneva 2004; Kasatkin 2007; Baklanova 2008; Volkova \& Safonova 2010) and voluminous records of oral and written texts of individual representatives of folk speech culture were published (Ossipov 1995; Russinova 2007; Felde 2010; Batyreva 2011).

As one may see, the number of objects of lingvopersonological research has steadily increased. The number of large-scale projects carried out by research teams is growing. Practically all of them (except for Shakhmatov's (1914) first experience) are long-term, over ten and more years. Study of a number of dialect language personalities that began several decades ago is still underway.

\section{Objects of research}

Individual speakers of local dialects are typical objects of dialectological research. These are mainly elderly women who were born at the end of the nineteenth and the beginning of the twentieth century. They are mostly semiliterate members of large peasant families, and engaged in unskilled physical work all their lives. Having been raised in the environment characteristic of the Russian peasantry, they retained features of language and mentality that are particular to traditional Russian culture. The speech of these village inhabitants, though bearing common typological features, differs in its expressiveness and manifestation of the source of individuality. The language of generations of young and middle-aged dialect speakers, who are subjected to strong influence of the literary language, has not been analyzed yet from the lingvopersonological perspective.

Informants represent the main dialects of the Russian language and different dialect zones and regions. Scientists have given special attention to speakers of the North Russian dialect (the South Russian is represented much more weakly) and the 
dialects of secondary formations, created in the territories of later settlements (Siberia and the Far East).

\section{Data sources}

First of all, records of individual speech of dialect speakers serve as sources for studying their oral speech. Until the 1970s they were handwritten without the use of technology. The majority of texts of the later period were recorded on a magnetic tape. Materials gathered in recent years are partly represented on digital media.

It is difficult to correlate data on the volume of records made as they are not present in every publication. When they are mentioned, the volume varies considerably and is measured in different units: more than 200 pages computer-typed, 1400 expressive units (Nefyodova 2000), 2476 pages of records made by hand (Gruzberg \& Egoryeva 1969), 16 hours of tape recordings (Almukhamedova et al. 1986), and over 5000 tests (Lyutikova 1999). The biggest idiolect data archive - about 10,000 pages of records of speech of a Russian longtime resident of Siberia transcribed from a tape recorder - belongs to Tomsk linguists (Ivantsova 2006-2012, vol. 1, 13).

The range of sources to study the dialect language personality is increased by written texts, which in general are less typical for the unwritten folk speech culture. So, when studying Agafya Lykova's language personality, about 100 letters written to different addressees using half-uncial writing are used (Tolstova 2004). Autobiographical notes of a Siberian peasant V. A. Plotnikov (Ossipov 1995) and the unusual diaries of a dialect speaker M. P. Suslova have been published and described (Russinova 2007).

\section{Methods of collecting material}

Methods of collecting material are being developed and improved. The observation method in combination with various types of polls is traditional for dialectology. With lingvopersonological research evolving, a method of inclusion is 
implemented in field practice, i.e., inclusion into the language being of the speaker, which means establishing close relationships with the informant, regular long-term observation, and creation of a situation in the course of recording that is comfortable for the individual. Application of this method allows better approaching the situation of open recording in conditions where free speech is generated in the natural language environment and provides an opportunity to gather facts about both an individual's discourse and the speaker's personality (Ivantsova \& Solomina 2014).

The formation of methods of inclusive observation may be promoted by kinship between collectors and dialect speakers. Thus, Timofeev had been recording the speech of his mother E. M. Timofeeva for more than 20 years (Timofeev 1971), and Lyutikova (1999) had been doing so with her mother's speech (V. M. Petukhova) for approximately the same length of time. However, in a number of dialectological projects absence of family relations was successfully compensated by confidential relations. Inclusion in the language being of the speaker was practiced by the Perm researchers who had been writing down A. G. Gorshkova's speech for about ten years (Skitova \& Ogiyenko 1971) and by the Tomsk dialectologists who studied V. P. Vershinina's speech systematically for 24 years. Elements of this method were applied in other lingvopersonological projects, though the degree of confidentiality between informants and collectors was different in every case.

\section{Aspects of research}

Both traditional and relatively new areas of analysis have been applied to researching idiolects of individual dialect speakers.

Within dialectological traditions, phonetic and grammatical phenomena of the individual speech of peasants, typical to their dialects, are described: features of vocalism and consonantism, inflexions of content words, and some syntactic characteristics (originality of functions of auxiliary parts of speech, word compatibility, and specific types of sentences). The idiolect of the person who bears a folk speech culture is perceived in these cases as "a chip of the dialect". Conclusions are drawn 
about its complete or incomplete coincidence with the dialect which is native for the individual (Timofeev 1971: 121-138; Lyutikova 1999: 20-40; Prokofieva 2012: 43-101). Phonetic and grammatical phenomena that characterize the author as a representative of a certain dialect group are also reconstructed in written texts of dialect speakers on the basis of analyzing deviations from literary norms. In addition, the way dialect speakers master written and literary language is considered through analysis of graphics, spelling, punctuation, and clichéd word combinations (Ossipov 1995; Batyreva 2011: 39-56).

The analysis of the lexical tier of the language system of dialect speakers focuses interest not only on locally limited lexical units (Timofeyev 1971, 2003; Lyutikova 1999, 2000; Nefyodova 1997, 2000, 2001), but also on the later tendency of the system analysis of the individual lexicon. The latter deals not only with lexemes that coincide with the literary language but also with those that don't coincide (Skitova \& Ogienko 1971; Malysheva 2007; Ivantsova 2002, etc.). In works on lexicon, thematic classification of the individual lexicon is considered (Timofeyev 1971: 121-138). Many papers are devoted to separate groups of words in the idiolexicon: diminutives (Andreyeva \& Gorlanova 1971), confessional nominations (Tolstova 2007), expressional and emotional elements (Nefyodova 1997), and some others. The description of the lexicon of a Siberian peasant V. P. Vershinina includes research of its all-Russian, colloquial, and dialect component, new and archaic vocabulary, nonce words and expressives, and also the main types of system relations of lexemes (motivational, alternative, synonymic and antonymic ones) (Ivantsova 2002: 36-160). Some authors also study quantitative characteristics of a dialect speaker's lexicon: its volume, the division of words into grammatical classes, a ratio of polysemantic and monosemantic units, and the rate of their use (Timofeyev 1971; Skitova \& Ogiyenko 1971; Lyutikova 1999; Ivantsova 2002).

The fact that discourse research was developed at the beginning of the twentyfirst century sparks keen interest in text created by a dialect speaker. General features of the structure of the text of the dialect language personality are considered (Ivantsova 2002: 180-250), as well as expressive means of the text - first of all, comparisons and metaphors (Lyutikova 1999; Ivantsova 2002; Volkova 2004), and a folklore component of the household discourse: proverbs, sayings, and humorous rhymes (chastushkas) 
(Lyutikova 1999; Malysheva 2007: 115-130). The system of speech genres of an idiolect becomes a subject of close attention (Demeshkina 1997; Gyngazova 2001; Kazakova 2007). In written texts of dialect speakers - diaries, memoirs, and letters - their substantial and structural features are analyzed. They are compared with oral texts on a similar subject produced by the same informants. This allows revealing common features of these two types of texts - "colloquiality" of speech and contrasting features (Ossipov 1995; Russinova 2007).

A new aspect of studying of the dialect text is research of the reflection of personality over language as an important part of consciousness of the individual mirrored in the text. The metalanguage reflection in the speech of dialect speakers is thoroughly studied (Blinova 1984; Mikitina 1989; Rostova 2000) including that in separate idiolects (Sakharny \& Orlova 1969; Lyutikova 1999; Ivantsova 2009). Forms of manifestation of metalanguage consciousness, the area of reflection, strategies of understanding of semantics of a dialectal word by the speaker, and particularities of assessing one's own speech and of the speech of people around are discovered.

Papers published in recent years have investigated the conceptosphere of specific representatives of folk oral culture based upon the data and the vocabulary test of dialectal language personalities. In a series of publications Gyngazova (2008, 2009, 2010, etc.) considered a system of key concepts of folk culture in the idiolect of the Siberian peasant V. P. Vershinina: HOUSE, LAND, LABOR, LIFE and DEATH, GOD, SIN, WAY, SPACE, BODY, SOUL, and others. Prokofieva (2012) analyzed such concepts as HOME, FAMILY, VILLAGE, WORLD, and GOD in the idiolect of the Altai dialect speaker A. V. Medvedeva. In the works of Ivantsova (2002, 2009, 2014), Volkova (2004), Russinova (2007) and Kuznetsova (2015) a particular picture of the world, the worldview, and the outlook of the dialect language personality were identified.

On the basis of the speech data of individual dialect speakers, the following problems were raised: problems of the creative beginning in the speech of ordinary native speakers (Lyutikova 1999; Prokofieva 2012), problems of detecting relic dialect features (Almukhamedova et al. 1986; Tolstova 2007), typological features of the dialect of the language personality (Ivantsova 2014), and the relation of language elements of an idiolect and a dialect (Gruzberg \& Egoryeva 1969). 
Dialect lexicography received a new impetus for its development. In the second half of the twentieth century not only the dialect speech of certain regions, but that of specific language personalities, became the object of lexicography. A special type of an idiolect dictionary of a dialect speaker with its different subtypes was created:

- a differential dictionary that includes only locally restricted units (Timofeev 1971; Lyutikova 2000);

- a non-differential dictionary, which reflects all-Russian dialect elements and dialect elements in a narrow sense on an equal footing (Tolstova 2004; Ivantsova 20062012);

- a general-type explanatory dictionary (includes all of the above);

- aspect dictionaries of an idiolect, the purpose of which is lexicographic representation of individual lexical classes of an idiolexicon, the means of expressive speech of an individual, and frequency characteristics of the text. Among the most recently published dictionaries are, An Expressive Dictionary of a Dialect Personality (Nefyodova 2001), Phraseology of a Dialect Personality (Timofeev 2003), and An Idiolect Dictionary of Comparisons of a Longtime Siberian Resident (Ivantsova 2005).

The range of aspects and problems of the study to be solved on the basis of data of individual dialect speakers is constantly expanding.

The study of individual speech of dialect speakers evolves from describing an idiolect as a "point representative of a dialect" to the dialectical understanding of the speakers' similarities and differences, and from analyzing only linguistic features of the individual to analyzing the personality of a native speaker, in which both a linguistic and an extralinguistic component are present. Researchers raise questions about conditions in which speech abilities of a speaker are formed in the dialect environment, about a speaker's mental attitudes and ethical and aesthetic preferences in a unique combination of typical features for traditional peasant communities and unique features of the individual.

It is frequent that studies are complex, multidimensional, and have a clearly marked lexicographic component. 


\section{Methods of research}

Analysis of the practice of studying speech of specific representatives of folk speech culture has shown that scientists use well-known general scientific methods, purely linguistic ones as well as new task-oriented methods for the study of the phenomenon of the language personality. From the group of universal interdisciplinary methods the main method is that of scientific description, involving a systematic inventory of language units and their taxonomic characteristics for formal, substantial, and functional properties (Skitova \& Ogienko 1971; Tolstova 2007; Batyreva 2011). The group of purely linguistic methods is dominated by the recently recognized independent lexicographic method, which is applied not only as a way to present the language material, but as an instrument of its analysis. The range of special lingvopersonological methods is represented by methods of speech portraiture and reconstruction of the language personality.

Speech portraiture rests on observable facts and is a story-like characteristic of the speech of the individual emphasizing its vivid features. In dialectology the most common type of a speech portrait includes brief biographical information about the informant, fragments of the informant's voice recordings, and the description of the non-literary features of idiolect phonetics, grammar, and vocabulary (Slesareva 1997; Oglezneva 2004; Kasatkin 2007; Baklanova 2008; Batyreva 2011).

The method of reconstructing the language personality is based on Karaulov's ideas and presupposes not only analyzing the linguistic means of the individual, but also reconstructing the worldview, objectives, interests, and the outlook of a person that for a direct observer are too difficult to access. This method focuses on the language personality of the past, embodied in a literary text. The object of the study may be the author of the text (writer) and also its characters (Karaulov 1987). The application of this method to the new object - a modern individual, including an ordinary native speaker who uses mostly spoken language - allows us to apply this method in dialectology. The result of such research is cognitive reconstruction of features of the worldview and 
understanding of bearers of traditional folk speech culture in the works of Perm and Tomsk researchers.

The methodology of the largest projects to study the dialect language personality can be differentiated by a synthesis of the elements of the abovementioned methods.

\section{Conclusion}

Due to the development of an anthropocentric paradigm and the interaction of different linguistic disciplines, characteristic of modern science, a new object of study a dialectal language personality - has appeared in dialectology. Its articulation took place for most of the last century and was characterized by:

- the appearance of works that not only describe a particular dialect as a whole, but also some of its speakers;

- a change of the focus of analysis from the speech of a particular dialect speaker as an illustration of usual characteristics of the dialect to research whose core of analysis is an individual who becomes a "starting point" in the study of a language;

- approbation of the method of inclusion in the linguistic being of the speaker in order to collect material under conditions as close as possible to the situation of spontaneous speaking of a dialect speaker;

- the creation of databases of scientific study of dialect language personalities based on a considerable number of records of oral speech and written texts of "naive authors";

- the creation of methods for studying the phenomenon of a dialect language personality.

Attention to the new object - the personality of the dialect speaker - is very significant for dialectology and lingvopersonology, at the junction of which studies of individual dialect speakers develop, as well as for linguistics in general.

In dialectology the study of the language personality allowed obtaining previously unknown information about quantitative and qualitative features of the vocabulary of peasants, particularities of speech culture in folk dialects, and originality of 
communication in the dialect, and gave an impetus to developing new types of dialect dictionaries.

Analysis of individual speech of dialect speakers played a crucial role in shaping the general theory of lingvopersonology. It enriched the concept of a language personality, the spectrum of methods of collecting and analyzing data, the sources of speech data of ordinary speakers, and typological features of a bearer of folk speech culture. Theoretical generalizations from the study of individual representatives of dialects are now being implemented into researching other types of language personalities - speakers of the literary language, the urban colloquial language and jargon, elite personalities, and historical figures.

Studying the phenomenon of a dialect language personality becomes a "pilot site" for formulating and solving many general linguistic problems. In lingvopersonological works dialectologists have raised global questions about the genesis of the language personality (factors influencing its formation and development), and connections and differences in speech of the individual and the language of society to which he or she belongs, by defining the typical and the individual in an idiolect, features of national culture (the fundamental principle of which is a traditional national culture), and particularities of a discourse practice in the contemporary language community.

\section{References}

AlmukHAMedova, Z. et al. (1986) “Из наблюдений над речью Лыковых - старожилов на реке Абакан" [From observation of the Lykovs' speech - longtime residents on the Abakan River], Phonetics and Writing, Ustinov, 103-115.

ANDREYEVA, L. \& N. GoRlanOVA (1971) “Существительные с уменьшительно-ласкательными суффиксами в народно-разговорной речи" [Nouns with diminutive-hypocoristic suffixes in folk conversational speech], Living word in the Russian speech of Prikamye, Perm, Issue 2, 71-78.

ASAHI, Yoshiyuki (2009) "Cookbook method and koine-formation: A case of the Karafuto dialect in Sakhalin", Dialectologia, 2, 1-21.

<http://www.publicacions.ub.edu/revistes/dialectologia2> 
BAKHTIN, M. (1996) Проблема речевых жанров [The problem of speech genres], in M. Bakhtin, Collected works, Moscow, Russian dictionaries, 159-206.

BAKLANOVA, I. (2008) “Речевой портрет диалектоносителя (на материале пермских говоров)” [Speech portrait of a dialect speaker (on the material of Perm dialects)], Russian in Action. Glazov, 123-127.

BAtYREVA, L. (2011) Речевой портрет провинциала (на материале частной переписки 1940-1945 г2. палехского крестьянина А.Н. Савельева) [Speech portrait of a provincial (on the material of private correspondence of 1940-1945 of A. N. Savelyev, a Palekh peasant)], Shuya, 175.

BaUdouin De CoURTenaY, J. (1963) Избранные труды по общему языкознанию, Т. 1-2. [Selected works on general linguistics (in 2 vol.)], Moscow: Publishing House of USSR Academy of Sciences.

BLINOVA, O. (1984) “Носители диалекта - о своем диалекте (об одном из источников лексикологического исследования)" [Dialect speakers about their dialect (about one of the sources of lexicological studies)], Siberian dialects of Russian, Tomsk, 3-15.

BogIN, G. (1984) Модель языковой личности в ее отношении к разновидностям текстов [Model of language personality in its relation to varieties of texts], abstract of doctoral dissertation, Leningrad, $31 \mathrm{p}$.

BuschmanN, E. \& W. VON HUMBoldt (2000) Wörterbuch der Mexicanischen Sprache, Manfred Ringmacher (ed.), Paderborn: Schöningh.

DEMESHKINA, Т. (1997) “Жанровые формы диалектной речи (на материале языка личности)” [Genre forms of dialect speech (on the material of the language of a personality)], Phenomenon of variability. Kemerovo, 122-129.

FELDE, О. (2010) “«Была ужасная пора, о ней свежо воспоминанье...» Устные рассказы жительницы села Степной Баджей Манского района Красноярского края Семенковой Галины Васильевны" ["There was an awful time, fresh is the reminiscence about it ..." Oral stories of Semenkova Galina Vasilyevna, inhabitant of the Stepnoy Badzhey village of the Mansky Region of the Krasnoyarsk Krai], Siberia Lingua. Scientific journal. Krasnoyarsk, No 2, 184-219.

<http://ifiyak.sfu-kras.ru/sites/language.institute.sfu-kras.ru/files/Siberia_Lingua_no_2.pdf>

FILLMORE, Charles J., Daniel KEMPLER \& William S-Y. WANG (eds.) (1979) Individual differences in language ability and language behavior, New York: Academic Press, 346.

GOLEV, N. (2004) Лингвоперсонологическая вариативность языка [Individual variability of language], Bulletin of Altai State University, 4, 41-45. 
Dialectologia 17 (2016), 91-109.

ISSN: 2013-2247

GRUZBERG, L. \& M. EGORYEVA (1969) “О соотношении языка говора и речи одного носителя говора (на материале вводных элементов)" [On the ratio of a dialect and the speech of one dialect speaker (on the material of introductory elements)], Living word in the Russian speech of Prikamye, Perm, 65-75.

GYNGAZOVA, L. (2001) “О речевом жанре воспоминания (на материале языка личности)” [On a speech genre of reminiscence (on the material of the language of a personality)], Modern directions of functional linguistics, Tomsk, 167-174.

GyNGAZOVA, L. (2008) “Физическое и духовное пространство в дискурсе носителя традиционной культуры" [Physical and spiritual space in the discourse of a bearer of traditional culture], Pictures of the Russian world: Spatial models in the language and in the text, Tomsk: UFO-PLUS, 78-109.

GYNGAZOVA, L. (2009) “Интерпретационный потенциал соматизмов в описании картины мира языковой личности диалектоносителя" [Interpretative potential of somatisms in the description of the picture of the world of a dialect speaker's language personality], Vestnik of Tomsk State University, Philology, Tomsk. No 1(5), 13-22.

GYNGAZOVA, L. (2010) “Метафорическое миромоделирование в дискурсе языковой личности" [Metaphorical world modeling in the discourse of the language personality], Vestnik of Tomsk State University, Philology, Tomsk, 1(9), 7-11.

IVANTSOVA, Е. (2002) Феномен диалектной языковой личности [Phenomenon of the dialect language personality], Tomsk: Tomsk State University Publishing House, 312.

IVANTSOVA, Е. (2005) Идиолектный словарь сравнений сибирского старожила [The Idiolect Dictionary of Comparisons of a Siberian Longtime Resident], Tomsk: Tomsk State University Publishing House, 162.

IVANTSOVA, E. (ed.) (2006-2012) Полный словарь диалектной языковой личности [Unabridged Dictionary of a Dialect Language Personality], Vol. 1-4, Tomsk: Tomsk State University Publishing House.

IVANTSOVA, E. (2009) Метаязыковое сознание диалектной языковой личности [Metalanguage consciousness of the dialect language personality], Everyday language consciousness: Ontological and gnoseological aspects, in N. D. Golev (ed.), Part. 1. Kemerovo - Barnaul: Altai State University Publishing House, 321-356.

IVANTSOVA, Е. (2010) Лингвоперсонология: Основы теории языковой личности [Lingvopersonology: Foundations of the theory of the language personality], Tomsk: Tomsk State University Publishing House, 160. 
IVANTSOVA, Е. (2014) Исследование типологических черт диалектной языковой личности [Research of typological features of the dialect language personality] Language personality: Modeling, typology, portraiture (Siberian lingvopersonology), in N. D. Golev \& N. N. Shpilnaya (eds.), Moscow: Lenand, 309-348.

IVANTSOVA, E. \& E. SOLOMINA (2014) “Об эффективных методах записи спонтанной устной речи при изучении языковой личности" [On effective methods of record of spontaneous oral speech when studying the language personality], Vestnik of Tomsk State University. Philology, No 3(29), 14-27.

JOHNSTONE, Barbara (1996) The linguistic individual. Self-expression in language and linguistics, New York/Oxford: Oxford University Press, 210.

KARAULOV, Yu. (1987) Русский язык и языковая личность [The Russian language and the language personality], Moscow: Science, 262.

KASATKIN, L. (2007) “Фрагмент языкового портрета донской казачки” [A fragment of the language portrait of a Don Cossack woman], Language in action, Moscow, 231-240.

KAZAKOVA, O. (2007) Диалектная языковая личность в жанровом аспекте [The dialect language personality in the genre aspect], Tomsk: Tomsk Polytechnic University Publishing House.

KUZNETSOVA, S. (2015) Вербализация чувственного восприятия как отражение перцептивной картины мира диалектной языковой личности [Verbalization of perception as a reflection of the perceptive world view of the dialect speaker], PhD dissertation, Tomsk.

LYUTIKOVA, V. (1999) Языковая личность и идиолект [The language personality and an idiolect], Tyumen: Tyumen University Publishing House, 188.

LYUTIKOVA, V. (2000) Словарь диалектной личности [The Dialect Personality Dictionary], Tyumen: Tyumen University Publishing House, 188.

MALYSHEVA, V. (2007) Идиолексикон сквозь призму лексикографии [Idiolexikon through a lexicography prism], Issue 1, Perm, 136.

Markelov, V. (2000) “Письма Агафьи Лыковой” [Agafya Lykova's letters], Russian Speech, No 4, $65-73$.

NeFYOdOVA, E. (1997) “Экспрессивный потенциал языковой (диалектной) личности” [Expressional potential of the language (dialect) personality], Issues of Russian Linguistics, Issue 7, Russian dialects: History and modern times, Moscow, 220-229. 
Dialectologia 17 (2016), 91-109.

ISSN: 2013-2247

NefyodoVA, E. (2000) “Идиолект как источник диалектного варьирования” [An idiolect as a source of a dialect variation], Materials and research on Russian dialectology, Moscow, Issue 1 (7), 251-262.

NeFYOdOVA, E. (2001) Экспрессивный словарь диалектной языковой личности [Expressional Dictionary of the Dialect Language Personality], Moscow: Moscow State University Publishing House, 144.

NEROZNAK, V. (2003) “Лингвокультурология и лингвоперсонология" [Cultural linguistics and Lingvopersonology], The Tower of Babel-2: Word. Text. Culture. Reading 2002-2003, Moscow, 13-17.

NIKITINA, S. (1989) "Языковое сознание и самосознание личности в народной культуре" [Language Consciousness and Self-Consciousness in Folk Cuture]. Language and Personality, Moscow, 34-40.

OGLEZNEVA, E. (2004) “Социально-речевой портрет современного диалектоносителя (на материале речи М.В. Хлыстова, жителя с. Чернавка Свободненского района Амурской области)" [The social and speech portrait of a modern dialect speaker (on the material of the speech of M. V. Hlystov, the inhabitant of the Chernavka village of the Svobodnensky Region of the Amur Region)], Folk speech of Primorye, Blagoveshchensk, 85-95.

Ossipov, B. (ed.) (1995) Автобиографические записки сибирского крестьянина В.А. Плотникова: Публикация и исследование текста [Autobiographical notes of a Siberian peasant V. A. Plotnikov: Publishing and research of the text] Preparation, foreword and commentary, Omsk: Omsk State University Publishing House.

OSthOFF, H. \& K. BRUGMAN (1881) Morphologische Untersuchungen auf dem Gebiete der indogermanischen Sprachen, Erster Theil, Leipzig <https://archive.org/details/morphologischeu00bruggoog>.

PAUL, H. (2002) Prinzipien der Sprachgeschichte, 10th Unrev. edition, Tübingen: Niemeyer.

PETKOV, S. (1983) Език и личност [Language and personality], Influence, Blagoevgrad.

Pound, Louis (1947) "The American Dialect of Charles Dickens", American Speech, vol. 22, No. 2, 124-130.

PRokofieVA, E. (2012) Диалектная языковая личность на Aлmae [A dialect language personality in Altai], PhD dissertation, Barnaul, 235.

Rostova, A. (2000) Метатекст как форма экспликации метаязыкового сознания [Metatext as a form of explication of metalanguage consciousness], Tomsk: Tomsk State 
University Publishing House.

Russinova, I. (ed.) (2007) Дневник М.П. Сусловой (1981-1985 гг.): Публикация и исследование текста [М. P. Suslova's diary (1981-1985): Publication and research of the text], Perm, 264.

SAKHARNy, L. \& O. ORLoVA (1969) “Типы употребления в речи нескольких вариантов одной гиперлексемы (опыт психолингвистического анализа текста)" [Types of usage of several options of one hyperlexeme in speech (experience of the psycholinguistic analysis of the text)], Living word in the Russian speech of Prikamye, Perm. Issue 1, 83-113.

SAPIR, Edward (1949) Selected writings of Edward Sapir in language, culture, and personality, David G. Mandelbaum (ed.), Berkeley: University of California Press.

SнакнматоV, А. (1914) Описание лекинского говора Егорьевского уезда Рязанской губернии [Description of the Lekinsky dialect of the Egoryevsky District of the Ryazan Province], St. Petersburg, 48.

SKITOVA, F. \& E. OGIYENKo (1971) “Из наблюдений над словарным запасом одного человека" [From observation of the lexicon of one person], Living word in the Russian speech of Prikamye, Perm. Issue 2, 26-39.

SlesAREVA, G. (1997) “Звуковой портрет Агафьи Лыковой” [A sound portrait of Agafya Lykova], Proceedings of the International Council of Experts in Russian Language and Literature in Krasnoyarsk, vol. 1, 173-174.

TIMOFEYEV, V. (1971) Диалектный словарь личности [A dialect dictionary of a personality], Shadrinsk, 141.

TIMOFEYEV, V. (2003) Фразеология диалектной личности: Словарь [Phraseology of a dialect personality: Dictionary], Shadrinsk: Shadrinsk Pedagogical Institute Publishing House, 176.

Tolstova, G. (2004) Словарь языка Агафьи Лыковой [A Dictionary of Agafya Lykova's language], Krasnoyarsk.

Tolstova, G. (2007) Старообрядческая конфессиональная лексика в письменной речи Агафьи Лыковой [Old Believers' confessional lexicon in Agafya Lykova's written language], abstract of PhD dissertation, Kemerovo, 28.

VinogRAdOV, V. (1980) Избранные труды. О языке художественной прозы. [Selected works. About language of fiction], Moscow, Science.

Volkova, N. \& E. SAFOnOVA (2010) “Языковая личность в диалектном пространстве” [A language personality in the dialect environment], Vilniaus pedagoginis universitetas, vol. $12,55-59$. 
Dialectologia 17 (2016), 91-109.

ISSN: 2013-2247

Volkova, T. (2004) Сравнения в речи диалектной языковой личности [Comparisons in the speech of the dialect language personality], PhD dissertation, Tomsk, 237.

WeISGERBER, L. (1929) Muttersprache und Geistesbildung, Göttingen: Vandenhoeck Ruprecht. 